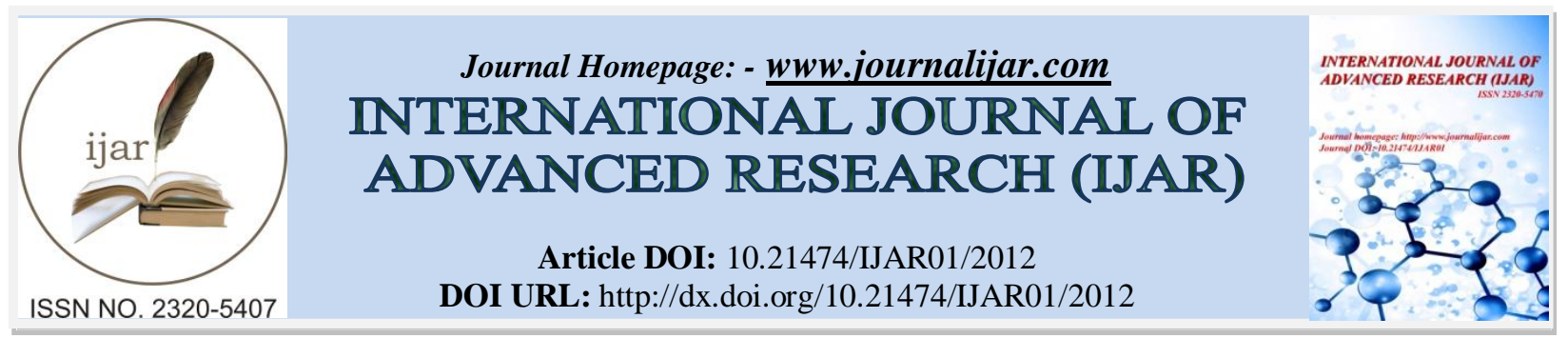

RESEARCH ARTICLE

\title{
SINGLE NUCLEOTIDE POLYMORPHISMS (SNPS) IN EXON 3 AND 7 OF ESTROGEN RECEPTOR BETA (ESR2) GENE IN WOMEN WITH BREAST CANCER FROM IRAQ.
}

\author{
*Sahar M. Hussain ${ }^{1}$, Hayfa H. Hassani ${ }^{2}$ And Mohsen H. Risan ${ }^{3}$. \\ 1. Department of Medical and Molecular Biotechnology, Al-Nahrain University. \\ 2. College of Biotechnology,Al-Nahrain University. \\ 3. Department of Agriculture Biotechnology, Al-Nahrain University.
}

\section{Manuscript Info}

Manuscript History

Received: 22 September2016

Final Accepted: 6 October 2016

Published: October 2016

Key words:-

ESR1 gene,ESR1 mutation, SNP in

breast cancer

\section{Abstract}

This study was aimed to determine the mutations and single nucleotide polymorphisms (SNPs) in exon 3 and 7 of estrogen receptor beta (ESR2) gene in women with breast cancer from Iraq. Different samples (blood, fresh tissue with blood from same patient, and formalin fixed paraffin embedded, FFPE) were collected from women with breast cancer. Molecular analysis exon 3 and 7 in ESR2 has been studied by using PCR. It was found exon 3 and 7 in ESR2 were revealed as a single band with size 151 and $157 \mathrm{bp}$, respectively. There was no SNP in exon 3 has been identified. While three novel polymorphisms (ACT, AGG and GCA) were detected in exon 7, the type of those polymorphisms deletion for ACT and AGG while substitution polymorphism for GCA. From this study, it can be concluded that some single nucleotide polymorphism in ESR1 and ESR2 may effect gene expression.

Copy Right, IJAR, 2016,. All rights reserved.

\section{Introduction:-}

Estrogen and its receptor (ER) play important roles in the genesis and malignant progression of breast cancer. ER alpha regulates the transcription of various genes as a transcription factor, which binds to estrogen response elements (ERE) upstream of the target genes [Ali and Coombes, 2002]. The expression of ER alpha is closely associated with breast cancer biology, especially the development of tumors; for example, breast carcinomas which lack ER alpha expression often reveals more aggressive phenotypes [Hayashi et al. 1997].

On the other hand, another ER, ER beta, was identified [Kuiper et al. 1996]. Subsequently, numerous studies have reported on the expression of ER alpha and beta in various cancers, including the observations in breast [Omoto et al. 2002], lung [Omoto et al. 2001], and stomach.

Immunohistochemical studies suggest that ER beta tends to beexpressed in ER alpha-positive breast cancers, and that there are ER alpha and ER beta co-expressing cells in human breast cancer. Furthermore, the existence of various variant forms of ER beta has been reported in breast cancer cells [Leygue et al. 1999].

Estrogen receptor beta was increasing interest in its role in human breast cancers, although its precise biologic role remains unclear, in part due to the fact that several isoforms exist. Studies examining ER beta have suggested that its expression may be a prognostic factor and predictive factor in patients with breast cancer, role for ER beta in breast 
cancer onset and progression [Chang et al., 2006; Hodges-Gallagher et al., 2008]. Nevertheless, up to $75 \%$ of invasive breast cancers have been shown to express ER beta, depending on the method used for its detection [Skliris et al., 2001; Fuqua et al., 2003].

The estrogen receptor alpha and beta encoded by estrogen receptor genes located on $6 \mathrm{q}$ and $14 \mathrm{q}$ respectively [Ascenzi et al., 2006]. Single nucleotide polymorphisms (SNPs) in specific candidate genes are thought to influence expression and/or activity of encoding proteins thereby predisposing to cancer, especially breast cancer [Siddig et al., 2008]. Importantly, the presence of mutations or SNPs in any of the estrogen receptors may have a serious effect on the production of estrogen and it subsequently would effect on the growth of cancer [Abbasi et al., 2012]. This study was aimed to determine the SNPs in exon 3 and 7 of estrogen receptor beta (ESR2) gene in Iraqi women with breast cancer.

\section{Materials and Methods:- Sample Collection:-}

Different samples (blood, frozen tissue and blood from the same patients, and formalin fixed paraffin embedded) were collected from 50 women, diagnosed and pathologically confirmed with breast cancer, with mean age $55.00 \pm$ 10 years attended to different hospitals in Bagdad from $1^{\text {st }}$ of April to $1^{\text {st }}$ of September 2014.24 of 50 samples recorded with estrogen receptor positive used in this study for detection of mutations in estrogen receptor beta. Besides, 10 samples of blood from healthy women with median age 45 years were included in this study as control. Those women had no history of breast cancer or any other neoplastic diseases, had no hysterectomy and artificial menopause, not exposed to any kind of radiation and chemotherapy in their lifetime. The blood samples collected and stored at $-4{ }^{\circ} \mathrm{C}$ until use for genotyping analysis.

\section{DNA extraction:-}

The DNA was extracted from different samples (blood, fresh tissue, and formalin fixed paraffin embedded) collected from patients and healthy groups. From blood samples, the DNA was extracted by using the Reliaprep blood genomic DNA MiniPrep system (Promega, USA) as described in the manufacturer's procedure. While DNA from fresh tissue samples was extracted by using Maxwell@ 16 Tissue DNA Purification Kit (Promega, USA) and Maxwell@ 16 instruments for automated purification of genomic DNA. In addition, DNA extraction from formalin fixed paraffin embedded (FFPE) samples was done by using ReliaPrep ${ }^{\mathrm{TM}}$ FFPE genomic DNA Miniprep (promega, USA).

The purity and concentration of extracted DNA from all samples were measured by NanoDrop apparatus. Then, the quality of DNA purification was determined by using gel-electrophoresis(Sambrok and Russell,2001).

\section{Polymerase Chain Reaction (PCR):-}

The extracted DNA from each sample was used as a template for $20 \mu \mathrm{l}$ PCR reactions. The PCR process was performed using 10 $\mu \mathrm{l}$ Go Taq ${ }^{\circledR}$ Green PCR Master Mix (Promega, USA), $1 \mu \mathrm{l}$ of $10 \mu \mathrm{m}$ from forward primer: TTGCTCCCTAGAGAGACACTGA and reverse primer: CTTCACACGACCAGACTCCA for exon 3 of ESR beta and the same value used for forward primer: GATGAGGGGAAATGCGTAGA and reverse primer:

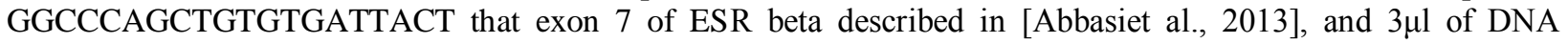
template. The mixture volume was completed to $20 \mu \mathrm{l}$ by adding free-nuclease water. PCR process was conducted through 30 cycles with the following steps: denaturation for $30 \mathrm{sec}$ at $95^{\circ} \mathrm{C}$, annealing for $30 \mathrm{sec}$ at $57^{\circ} \mathrm{C}$ and elongation for 40 seconds at $72^{\circ} \mathrm{C}$.

\section{DNA Sequencing:-}

In order to analyze the nucleotides sequences for all samples and to determine the presence of single nucleotide polymorphism (SNP), DNA sequencing was performed on both cancer patients and healthy individuals at the national instrumentation center or environmental management (NICEM), using the ABI prism 3100 xl genetic analyzer (Applied Biosystems, USA). 


\section{Result and Discussion:-}

Amplification of exons beta (ESR2) genes

The samples (blood, frozen tissue, and FFPE) that showed positivity to estrogen receptor protein were selected for molecular study. It has been selected 10 samples from blood, 7 sample from frozen tissue, and 7 samples from FFPE.

On the other hand, exon 3 and 7 in estrogen receptor beta (ESR2) appeared as a band with size $151 \mathrm{bp}$ and $157 \mathrm{bp}$ respectively as shown in fingers (1) and (2). In Iranian women, the size of exon 3 and 7 in ESR2 was also detected [Abbasi, 2010]. The exon 3 had the same sized that found in this study, while exon 7 showed different size with 329 $\mathrm{bp}$, this may due to the differences in PCR program.

A

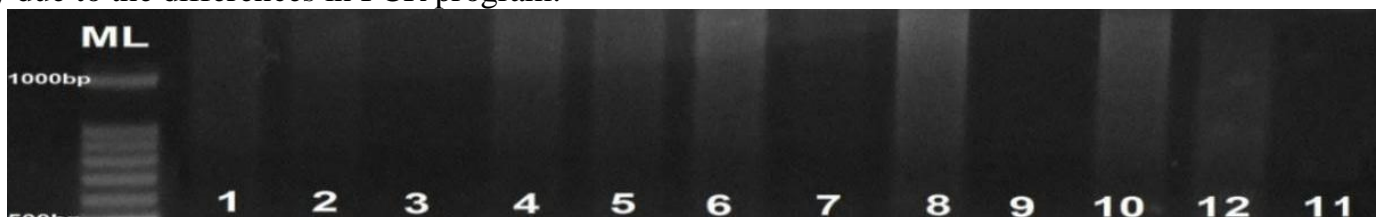

B

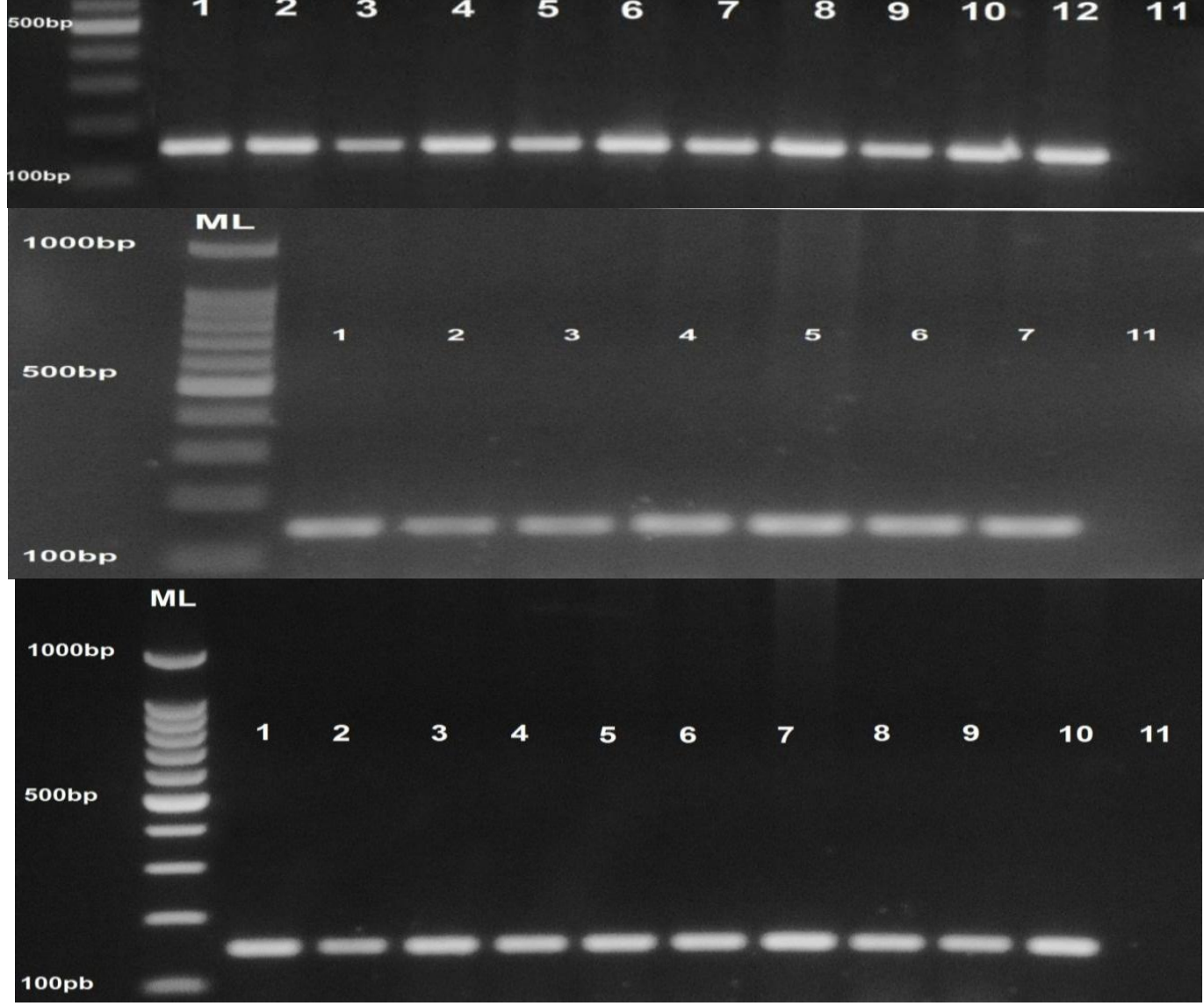

Figure 1:- Amplification of exon 3 in estrogen receptor beta set 1 primer with 151 bp. A: blood samples; Lanes 1-10 represent DNA from women with breast cancer, lane 11 represents control negative, lane 12 represents DNA from healthy subjects. B: frozen tissue samples; Lanes 1-7 represent DNA from women with breast cancer, lane 11 represents control negative. C. FFPE samples; Lanes 1-10 represent DNA from women with breast cancer, lane 11 represents control negative. Agarose $1.5 \%, 5 \mathrm{~V} / \mathrm{cm}$ for $45 \mathrm{~min}$, ML: molecular ladder 


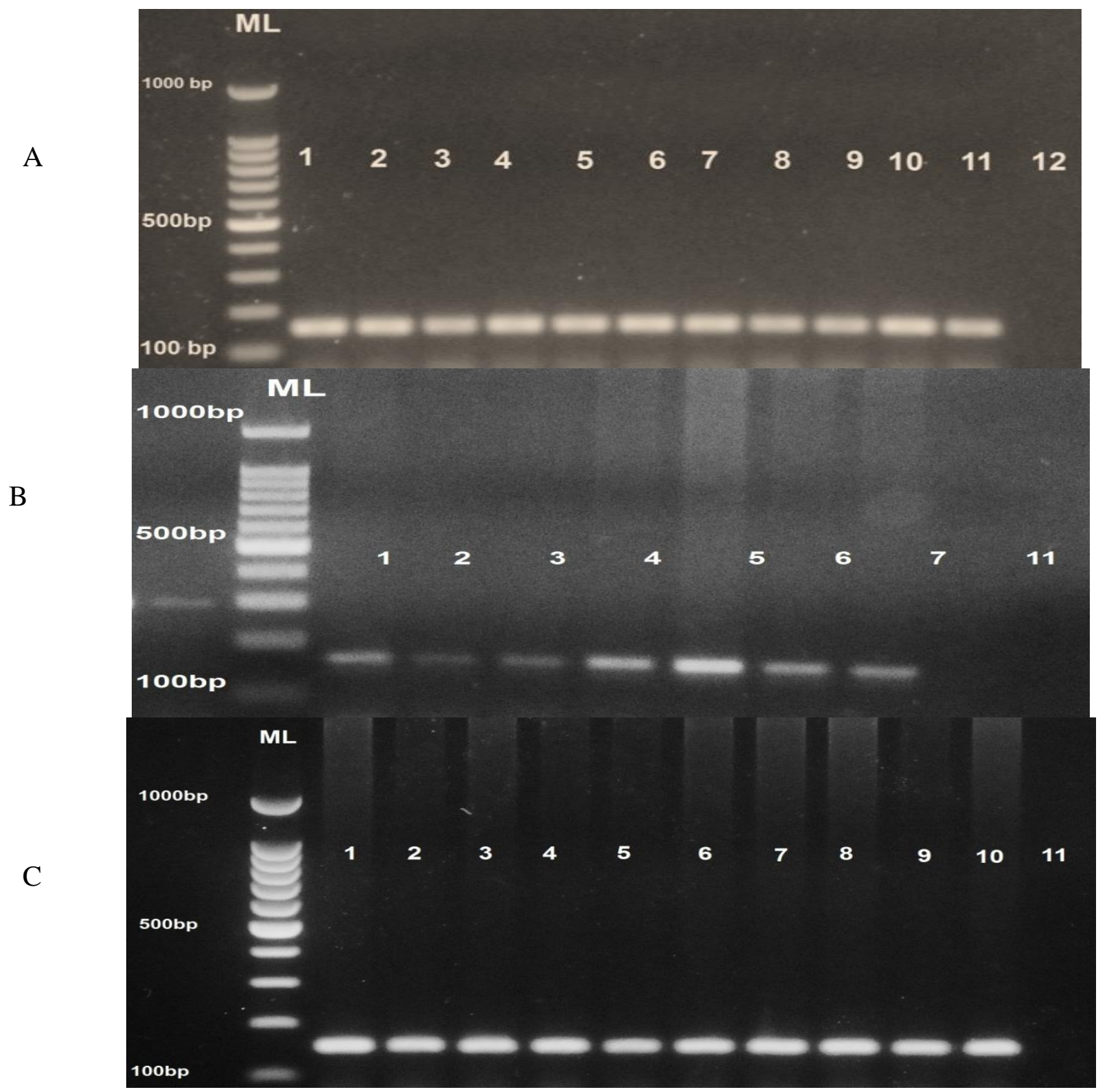

Figure 2:- Amplification of exon 7 in estrogen receptor beta set 1 primer with $157 \mathrm{bp}$. A: blood samples; Lanes 1-10 represent DNA from women with breast cancer, lane 11 represents control negative, lane 12 represents DNA from healthy subjects. B: frozen tissue samples; Lanes 1-7 represent DNA from women with breast cancer, lane 11 represents control negative. C. FFPE samples; Lanes 1-10 represent DNA from women with breast cancer, lane 11 represents DNA of control negative. Agarose $1.5 \%, 5 \mathrm{~V} / \mathrm{cm}$ for $45 \mathrm{~min}$, ML: molecular ladder.

Polymorphisms in estrogen receptor beta (ESR2):-

polymorphisms of exon 3 in ESR2:-

The results of nucleotide sequencing profile of exon 3 in ESR2 showed no polymorphisms in women with breast cancer when compared with healthy women. This result was similar to that found in Iranian population[Abbasiet al., 2009]. An alignment of nucleotides sequencing of exon 3 in women with breast cancer confirmed no polymorphisms were seen in this exon when compared with control in NCBI center using automated sequencer and analyzed by BLAST data as in finger (3). 
Polymorphisms in exon 7 of ESR 2:-

The polymorphisms in exon 7 of ESR2 in women with breast cancer were studied. The results indicated three polymorphisms (ACT, AGG, and GCA) (Table 1). Two of these polymorphisms (ACT, AGG) were deletion mutations (missense mutation) while the other (GCA) was substitution mutation (sense mutation).

Homo sapiens estrogen receptor 2 (ER beta) (ESR2), RefSeqGene on chromosome 14

Sequence ID: ref|NG_011535.1|Length: 118518Number of Matches: 1

Related Information

Map Viewer-aligned genomic context

Range 1: 63415 to 63537GenBankGraphics Next Match Previous Match First Match

Alignment statistics for match \#1

\begin{tabular}{|l|l|l|l|l|l|}
\hline Score & Expect & Identities & Gaps & Strand & \\
\hline 217 bits(117) & $\mathbf{4 e - 5 3}$ & $\mathbf{1 2 4 / 1 2 4 ( 0 \% )}$ & $\mathbf{0 / 1 2 4}(\mathbf{0 \%})$ & Plus/Plus & \\
\hline
\end{tabular}

\begin{tabular}{|c|c|c|c|}
\hline Query & 2 & AAGGTTAGTGGGAACCGTTGCGCCAGCCCTGTTACTGGTCCAGGTTCAAAGAGGGATGCT & 60 \\
\hline & & IIIIIIIIIIIIIIIIIIIIIIIIIIIIIIIIIIIIIIIIIIIIIIIIIIIIIIIIIIII & \\
\hline Sbjet & 63415 & AAGGTTAGTGGGAACCGTTGCGCCAGCCCTGTTACTGGTCCAGGTTCAAAGAGGGATGCT & 63473 \\
\hline Query & 61 & СACTTCTGCGCTGTCTGCAGCGATTACGCATCGGGATATCACTATGGAGTCTGGTCGTGT & 120 \\
\hline & & IIIIIIIIIIIIIIIIIIIIIIIIIIIIIIIIIIIIIIIIIIIIIIIIIIIIII & \\
\hline Sbjct & 63474 & CACTTCTGCGCTGTCTGCAGCGATTACGCATCGGGATATCACTATGGAGTCTGGTCGTGT & 63533 \\
\hline Query & 121 & GAAG 124 & \\
\hline Sbjet & 63534 & GAAG 63537 & \\
\hline
\end{tabular}

Figure 3:- Alignment of exon 3 in ESR2 gene sequence of women with breast cancer using automated sequencer was analyzed by BLAST data, query number represents the current results while the subject represents the reference sequence. Blue color represents exon region, black color represented intron region

Table 1:- Polymorphisms in exon 7 of ESR2 gene in women with breast cancer.

\begin{tabular}{|c|c|c|c|c|c|c|c|c|c|}
\hline No. & Polymorphism & Type & Position & $\begin{array}{c}\text { Wild } \\
\text { type } \\
\text { codon }\end{array}$ & $\begin{array}{c}\text { Mutated } \\
\text { codon }\end{array}$ & $\begin{array}{c}\text { Chang of } \\
\text { amino } \\
\text { acid }\end{array}$ & $\begin{array}{c}\text { Effect on } \\
\text { translation }\end{array}$ & $\begin{array}{c}\text { Kind of } \\
\text { mutation }\end{array}$ & $\begin{array}{c}\text { No. } \\
\text { of } \\
\text { patients }\end{array}$ \\
\hline $\mathbf{1}$ & Missing A & Deletion & 93926 & A-C & ACT & N $\rightarrow$ T & $\begin{array}{c}\text { Missense } \\
\text { mutation }\end{array}$ & $\begin{array}{c}\text { Point } \\
\text { mutation }\end{array}$ & 1 \\
\hline $\mathbf{2}$ & Missing A & Deletion & 93935 & A-G & AGG & K $\rightarrow$ R & $\begin{array}{c}\text { Missense } \\
\text { mutation }\end{array}$ & $\begin{array}{c}\text { Point } \\
\text { mutation }\end{array}$ & 6 \\
\hline $\mathbf{3}$ & T $\rightarrow$ A & $\begin{array}{l}\text { Substitu- } \\
\text { tion }\end{array}$ & 93918 & GCT & GCA & A $\rightarrow$ A & $\begin{array}{c}\text { Sense } \\
\text { mutation }\end{array}$ & $\begin{array}{c}\text { Point } \\
\text { mutation }\end{array}$ & 1 \\
\hline
\end{tabular}

Sequences and alignment of mutations in exon7 of ESR2:-

ACT and AGG:-

The nucleotide sequencing profile and an alignment for exon 7 in ESR2 gene in women with breast cancer were done as in finger(4). In the first polymorphism, the common codon AAC was converted to ACT, this type of mutation was effected gene expression because of alteration in amino acid was occurred; Asparagine was converted to Threonine.

While the common codon AAG was converted to AGG. This polymorphism caused changing in the protein because of conversion of amino acid; Lysine was changed to Arginine.

Homo sapiens estrogen receptor 2 (ER beta) (ESR2), RefSeqGene on chromosome 14

Sequence ID: ref|NG_011535.1|Length: 118518Number of Matches: 1

Related Information

Map Viewer-aligned genomic context

Range 1: 93905 to 94028GenBankGraphics Next Match Previous Match First Match

\begin{tabular}{|c|c|c|c|c|c|}
\hline \multicolumn{6}{|c|}{ Alignment statistics for match \#1 } \\
\hline Score & Expect & Identities & Gaps & Strand & \\
\hline 199 bits(220) & $7 e-48$ & $122 / 124(98 \%)$ & $2 / 124(1 \%)$ & Plus/Plus & \\
\hline
\end{tabular}




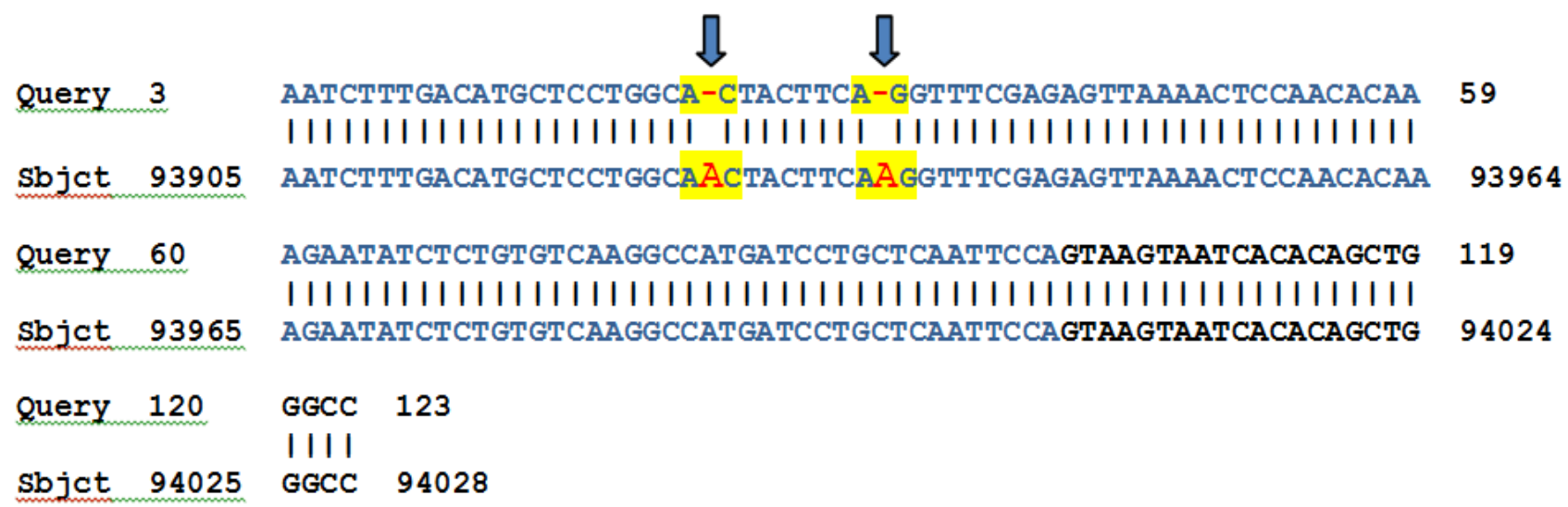

Figure 4:- Alignment of exon 7 in ESR2 gene sequence of women with breast cancer using automated sequencer was analyzed by BLAST data, query number represents the current results while the subject represents the reference sequence. Blue color represents exon region, black color represented intron region while the single nucleotide polymorphism represents red color.

\section{Snp gca:-}

The nucleotide sequencing profile and alignment for exon 7 in ESR2 gene in women with breast cancer as in finger (5) was done. The silent polymorphism GCA was a substitution mutation in which the common codon GCT was converted to GCA. This point mutation had no effect on gene expression in which the altered codons still encode the same amino acid, Alanine.

Homo sapiens estrogen receptor 2 (ER beta) (ESR2), RefSeqGene on chromosome 14

Sequence ID: ref|NG_011535.1|Length: 118518Number of Matches: 1

Related Information

Map Viewer-aligned genomic context

Range 1: 93873 to 93988GenBankGraphics Next Match Previous Match First Match

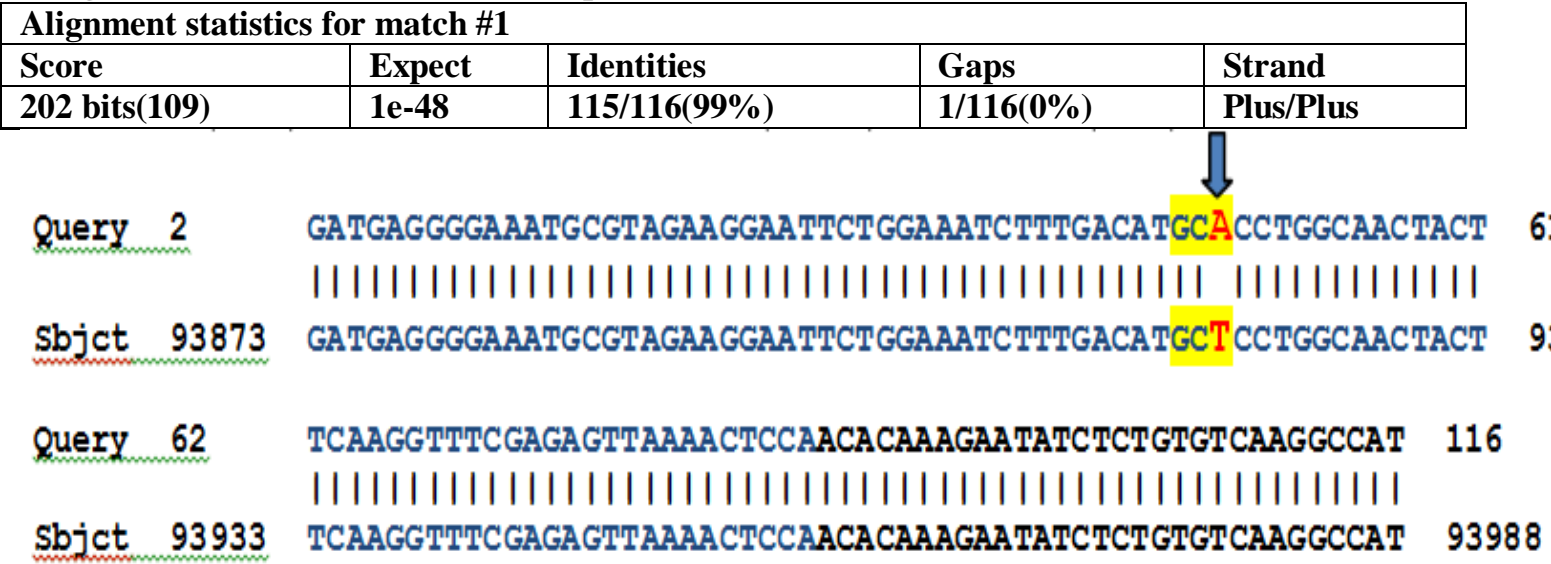

Figure 5:- Alignment of exon 7 in ESR2 gene sequence of women with breast cancer using automated sequencer was analyzed by BLAST data, query number represents the current results while the subject represents the reference sequence. Blue color represents exon region, black color represented intron region while the single nucleotide polymorphism represents red color

Regarding to the deletion mutations, ACT and AGG, that found in exon 7of ESR2. These polymorphisms may cause a frame shift in the translational region. The frame shift had a higher effect on the polypeptide, in addition this type of genetic difference lead to variation in copy number. Variation in gene copy number might influence the activity of genes and this lead to developing many diseases in human body and resist to drugs [Genetics Home Reference, 2016]. 
On the other hand, the single nucleotide polymorphism GCA that detected in exon 7 of ESR2 in Iraqi women was a silent polymorphism. Whereas in chines women another silent polymorphism C (33390) G L 392 L was detected by using direct sequencing of the ESR2 gene [Zheng et al., 2003].

Generally, there was positive association between breast cancer risk and single nucleotide polymorphisms (SNPs) in exon 7. Although it was a silent synonymous change, it may inactivate genes by inducing the splicing machinery to skip the exons [Cartegni et al., 2002]. In fact, the SNP located in an exonic splicing enhancer motif and may affect the accuracy and efficiency of ESR2 pre-mRNA splicing.

However, the role of ESR2 variants in breast cancer may work together with other genes in certain types of breast cancer and in certain populations.

In our results, the non-synonymous SNPs, ACT and AGG, in exon 7 of ESR2 are within the regulatory region of the genome coding to different amino acid so it may have deleterious effects because of their influence on protein activity. Brian et al., [2008] and Aurekha et al., [2009] concluded that if SNPs within regulatory regions of the gene, it caused disregulation of gene transcription and may change the structure folds of mRNA lead to influence gene expression.

On the other hand, in this work it was found a silent polymorphism (GCA) in exon 7of ESR2 gene. The studied polymorphism was a base-pair exchange in the third codon position central to the ESR1 gene that does not alter the encoded amino acid (synonymous). This polymorphism could be regarded as a marker, potentiality in linkage disequilibrium with another functional locus as represent by Wedre'net al. [2004]. It was reported that this polymorphism may indirectly affect the protein function through alteration of the RNA half-life or protein translation, hence indirectly affecting the level of ESR1 protein [Herynk and Fuqua, 2004].

Additionally study from the National Cancer Institute found that silent a SNP affected protein function because of enforcing the cell for reading a different DNA codon which it already does, while the aforesaid protein sequence eventually was made. Thus, silent change in an altered protein conformation leads to slow folding rhythm resulting, which functions in turn influence. These non-concordances provide an appraisement of the prevalence of allelic imbalance (AI) in normal breast tissue. Although AI may not be a cancer precursor, the frequency of AI in these cancer patients may be a demonstration of an aberrant ongoing malignant transformation process in an individual's breast tissue [Li et al., 2002; Braakhuis et al., 2003; Larson et al., 2005].

From the results above it can be concluded that there were specific SNPs (ACT and AGG) in exon 7 of ESR2 may contribute to the risk of breast cancer in Iraqi women with breast cancer.

\section{References:-}

1. Ali, S. and Coombes, R. C.. Endocrine-responsive breast cancer and strategies for combating resistance. Nat Rev Cancer.2002; 2, 101-112.

2. Hayashi, S. I., Eguchi, H., Tanimoto, K., Yoshida, T., Omoto, Y., Inoue, A., Yoshida, N., and Yamaguchi, Y.The expression and function of estrogen receptor alpha and beta in human breast cancer and its clinical application. Endo related cancer. 2003; 10(2), 193-202.

3. Kuiper, G. G. J.M., Enmark, E., Pelto-Hukko, M., Nilsson, S. and Gustafsson, J. A. Cloning of a novel estrogen receptor expressed in rat prostate and ovary.Endo related cancer. (1996);10(2),193-202.

4. Omoto, Y., Kobayashi, S., Inoue, S., Ogawa, S., Toyama, T., Yamashita, H., Muramatsu, M., Gustafsson, $\mathbf{J}$. and Iwase, H. Evaluation of oestrogen receptor beta wild-type and variant protein expression, and relationship with clinicopathological factors in breast cancers. European Journal of Cancer. 2002; 38,380-386.

5. Omoto, Y., Kobayashi, Y., Nishida, K., Tsuchiya, E., Eguchi, H.,Nakagawa, K., Ishikawa, Y., Yamori, T., Iwase, H., Fujii, Y., Warner, M.,Gustafsson, J. and Hayashi, S. Expression, function and clinical implications of estrogen receptor beta in human lung cancer. Biochemical and Biophysical Research Communications. 2001; 285, 340-347.

6. Leygue, E., Dotzlaw, H., Watson, P. H. and Murphy, L. C. Expression of estrogen receptor ESR1, ESR2, and messenger RNAs in human breast tissue. Cancer Research. 1999; 59,1175-1179.

7. Chang, E. C., Frasor, J., Komm, B., et al. Impact of estrogen receptor beta on gene networks regulated by estrogen receptor alpha in breast cancer cells. Endocrinology. 2006; 14,4831-4842. 
8. Hodges-Gallagher, L., Valentine, C. D., El Bader, S., et al. Estrogen receptor beta increases the efficacy of antiestrogens by effects on apoptosis and cell cycling in breast cancer cells. Breast Cancer Res Treat. 2008; 109, 241-250.

9. Skliris, G.P., Carder, P. J., Lansdown, M. R., et al.Immunohistochemical detection of ERbeta in breast cancer:towards more detailed receptor profiling?. Br J Cancer. 2001;84, 1095-1098.

10. Fuqua, S. A., Schiff, R., Parra, I., et al. Estrogen receptor beta protein in human breast cancer: correlation with clinical tumor parameters. Cancer Res. 2003; 63, 2434-2439.

11. Ascenzi, P., Bocedi, A., and Marino, M. Structure-function relationship of estrogen receptor [alpha] and [beta]: Impact on human health. Molecular Aspects of Med. 2006; 27, 299.

12. Siddig, A., Mohamed, A. O., Awad, S., Hassan, A. H., Zilahi, E., Al-Haj, A., Bernsen, R., and Adem, A. Estrogen Receptor $\alpha$ Gene Polymorphism and Breast Cancer. Ann. N.Y. Acad. Sci. 2008; 1138, 95-107.

13. Abbasi, S., Nouri, M., Azimi, C. Estrogen receptor genes variations and breast cancer risk in Iran. Int J ClinExp Med. 2012; 5(4), 332-341.

14. Abbasi S., Rasouli M., Nouri M., and Kalbasi S. Association of estrogen receptor- $\alpha$ A908G (K303R) mutation with breast cancer risk. Int J Clin Exp. 2013; 6(1), 39-49.

15. Abbasi S. Estrogen Receptor-Beta Gene Polymorphism in women with Breast Cancer at the Imam Khomeini Hospital Complex, Iran. BMC Med Genet. 2010; 11, 109.

16. Abbasi, S., Ismail, P., Othman, F., Rosli, R., and Azimi, C. Estrogen receptor- $\alpha$ (ESR1) gene, codon 594 (G3242A) polymorphism among Iranian women with breast cancer: a case control study. Asian J Scie Res. 2009; 2(1), 51-60.

17. Genetics Home Reference Mutations and Health Lister Hill. U.S. National Library of Medicine. National Institutes of Health Department of Health and Human Services.2016. https://ghr.nlm.nih.gov.

18. Zheng, S. L., Zheng, W., Chang, B. L., et al. Joint effect of estrogen receptor beta sequencevariants and endogenous estrogen exposure on breast cancer risk in Chinese women. Cancer Res. 2003; 63, 7624 -9.

19. Cartegni, L., Chew, S. L., and Krainer, A. R. Listening to silence and understanding nonsense: exonic mutations that affect splicing. Nat Rev Genet. 2002; 3, 285-298.

20. Brian, N. C., Xuting W., Michelle R. C., Gary S. P., Maher A. N., and Douglas A. B. Discovery and verification of functional single nucleotide polymorphisms in regulatory genomic regions: Current and developing technologies. Mutat Res. 2008; 659(1-2), 147-157.

21. Aurekha, D., Sailaja, K., NageswaraRao, D., Raghunadharao, D., and Vishnupriya, S.Oestrogen receptor beta (ER $\beta$ ) polymorphism and its influence on breast cancer risk. Journal of Genetics. 2009; 88(2): 101.

22. Wedre'n, S., Lovmar, L., Humphreys, K., et al.Oestrogen receptor $\alpha$ gene haplotype and post- menopausal breast cancer risk: a case control study. Breast Cancer Res. 2004; 6, 437-449.

23. Herynk, M. H. and Fuqua, S. A. Estrogen receptor mutations in human disease. Endocr Rev. 2004; 25, 869898.

24. Li, Z., Moore, D. H., Meng, Z. H. et al. Increased risk of local recurrence is associated with allelic loss in normal lobules of breast cancer patients. Cancer Res. 2002; 62, 1000-1003.

25. Braakhuis, B. J., Tabor, M. P., Kummer, J.A. et al. A genetic explanation of Slaughter's concept of field cancerization: evidence and clinical implications. Cancer Res. 2003; 63, 1727-1730.

26. Larson, P. S., Schlechter, B. L., de lasMorenas, A. et al. Allele imbalance, or loss of heterozygosity, in normal breast epithelium of sporadic breast cancer cases and BRCA1 gene mutation carriers is increased compared with reduction mamoplasty tissues. J ClinOncol. 2005; 23:8613-8619. 